\title{
A multi-adaptive framework for the crop choice in paludicultural cropping systems
}

\author{
Nicola Silvestri, ${ }^{1,2}$ Vittoria Giannini, ${ }^{2}$ Federico Dragoni, ${ }^{2}$ Enrico Bonari ${ }^{2}$ \\ ${ }^{1}$ Department of Agricultural, Food and Environmental Sciences, University of Pisa; ${ }^{2}$ Institute of Life \\ Sciences, Sant'Anna School of Advanced Studies, Pisa, Italy
}

\begin{abstract}
The conventional cultivation of drained peatland causes peat oxidation, soil subsidence, nutrient loss, increasing greenhouse gas emissions and biodiversity reduction. Paludiculture has been identified as an alternative management strategy consisting in the cultivation of biomass on wet and rewetted peatlands. This strategy can save these habitats and restore the ecosystem services provided by the peatlands both on the local and global scale. This paper illustrates the most important features to optimise the crop choice phase which is the crucial point for the success of paludiculture systems. A multi-adaptive framework was proposed. It was based on four points that should be checked to identify suitable crops for paludicultural cropping system: biological traits, biomass production, attitude to cultivation and biomass quality. The main agronomic implications were explored with the help of some results from a plurennial open-field experimentation carried out in a paludicultural system set up in the Massaciuccoli Lake Basin (Tuscany, Italy) and a complete example of the method application was provided. The tested crops were Arundo donax L., Miscanthus $\times$ giganteus Greef et Deuter, Phragmites australis L., Populus $\times$ canadensis Moench. and Salix alba L. The results
\end{abstract}

Correspondence: Nicola Silvestri, Department of Agricultural, Food and Environmental Sciences, University of Pisa, via del Borghetto 80, 56124 Pisa, Italy.

E-mail: nicola.silvestri@unipi.it

Key words: Crop choice; Multi-adaptive model; Paludiculture; Peatlands management.

Conflict of interest: the authors declare no potential conflict of interest.

Acknowledgements: this work was supported by the Ente di Bonifica Consorzio 1 Toscana nord and funded by Regione Toscana.

Conference presentation: SIA XLIV Congress, Bologna, 2015.

Received for publication: 15 February 2016.

Revision received: 20 July 2016.

Accepted for publication: 23 July 2016.

CCopyright N. Silvestri et al., 2017

Licensee PAGEPress, Italy

Italian Journal of Agronomy 2017; 12:734

doi:10.4081/ija.2016.734

This article is distributed under the terms of the Creative Commons Attribution Noncommercial License (by-nc 4.0) which permits any noncommercial use, distribution, and reproduction in any medium, provided the original author(s) and source are credited. showed a different level of suitability ascribable to the different plant species proving that the proposed framework can discriminate the behaviour of tested crops. Phragmites australis L. was the most suitable crop whereas Populus $\times$ canadensis Moench and Miscanthus $\times$ giganteus Greef et Deuter (in the case of biogas conversion) occupied the last positions in the ranking.

\section{Introduction}

Historically farmers have followed a simple and overall suitable rule in the use of agricultural land: the removal of limiting factors for crop production (Verhoeven et al., 1996). To comply with this criterion, farmers have used a large amount of mechanical, chemical and genetic inputs modifying natural ecosystems until getting to alter the pristine landscape conditions through irrigation, terracing, land reclamation, etc.

However, the application of these practices has often led to the development of unsustainable cropping systems, particularly when drastic changes on the environment were adopted to achieve high yield performances.

An example of the inefficacy of this approach is provided by the conventional drained-peatlands cultivation model. In previous centuries, many peatlands were artificially drained in Europe as a result of increasing land demand for agriculture and forestry (i.e. land-hunger) and the urgent need to improve sanitary conditions (i.e. malaria eradication) for the peatland population (Holden et al., 2006). More recently, pristine wetland habitats have continued to decrease as a consequence of the rising need for food, water and energy. Although there are no official statistics, the peatland reduction in Europe has been roughly estimated at around $80 \%$ of the total resources (Verhoeven, 2014).

The negative effects of this change in land use are numerous: i) an increase of GHG emissions (climate changes); ii) lowering of the soil level (subsidence phenomena); iii) the release of nitrogen and phosphorous compounds in the drainage water (eutrophication of receiving water body); iv) the loss of habitats for rare and threatened species (biodiversity reduction); v) the reduction of aquifer recharge (water scarcity and drought) (Holden et al., 2006; Wichtmann and Joosten, 2007; Litaor et al., 2008).

Moreover the conventional cultivation of drained peatland is no longer sustainable even in economic terms. The high drainage costs are borne not only by farmers and the viability of agriculture in these areas is strictly dependent on a wide sharing of the costs within the local community (Wichtmann et al., 2010).

To maintain an agricultural use of peatlands, a new strategy is required. We need to privilege an adaptive approach which is able to identify the most adequate solutions to allow the cultivation without altering the pristine environmental conditions. Paludiculture (lat. palus=swamp) is the cultivation of biomass on 
wet or rewetted peatlands and represents an alternative to the conventional cropping systems based on peatland drainage (Wichtmann and Schäfer, 2007; Wichtmann and Couwenberg, 2013; Verohoeven, 2014). The lack of drainage and the consequent restoration of wet conditions allow peatlands to provide once more those ecosystem services that are important both on local and global scale: carbon sink, flood detention, aquifers recharge, nutrients and contaminants retention, biodiversity conservation (Cicek et al., 2006; Zedler, 2003).

In order to fully profit by the potentialities of those areas, it is important to carefully select the agronomic practices which better fit peatland conditions (Wichtmann and Wichmann, 2011). Although every decision concerning the farming practices (machinery, fertilisation, water table level control, etc.) is important for a sustainable use of peatlands, the crop choice is crucial for the success of paludicultural system but still scarce literature is available about crop choice criteria (Giannini et al., 2015). The cultivated plant species have to satisfy several different requirements (Abel et al., 2013) and only by using a multi-adaptive approach (e.g. a methodology which takes into consideration all the numerous constraints), we can give a comprehensive response to this critical issue in the paludiculture system design.

In this paper, the evaluation of crop suitability was driven only by agronomic criteria. Indeed most of the above mentioned environmental benefits due to paludiculture can be considered, in a first approximation, independent from the chosen plant species but mainly related to the particular growing conditions implying a constant saturation of the peat body. We point out the features that should be considered for crop choice and we proposed a framework to evaluate the plant species suitability and to rank them in an order of preference. Moreover we reported an application example of the framework by using some research results from a study started in 2012 and still ongoing, which is carried out within a land-reclamation district in the west-central Italy (Tuscany).

\section{Materials and methods}

\section{Field experiment}

The data used for an example application of the multi-adaptive framework derive from a large experimental system (15 ha) carried out to compare the efficiency of three different systems in treating eutrophic drainage waters. The tested systems were a constructed wetland system (CWS), a natural wetland system (NWS), and a paludiculture system (PCS) (Figure 1). The last of these was based on the comparison among perennial rhizomatous grasses (PRGs): Arundo donax L., Miscanthus $\times$ giganteus Greef et Deuter, and Phragmites australis L., and woody crops managed as short-rotation coppice (SRCs): Populus $\times$ canadensis Moench. var. Oudenberg and Salix alba L. var. Dimitrios and an annual crop: Zea mays L. used as control because of its large spread in the cultivated areas (Silvestri et al., 2012). The experimental site, located

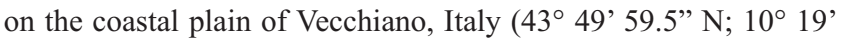
50.7 " E) was arranged on 5 ha of peaty soil, hydraulically isolated from the rest of land-reclamation district (Pellegrino et al., 2014). PRGs and SRCs were grown under paludiculture conditions thanks to a dense network of small channels (about $8 \mathrm{~m}$ apart) that supplied water to the fields, keeping the water table close to the soil surface (depth from 0.0 to $-0.2 \mathrm{~m}$ ). Maize was cultivated on the surrounding fields, characterised by deeper water table level (from -0.1 to $-0.6 \mathrm{~m}$ ) artificially lowered by pumping stations to allow the cultivation with the conventional practices. Further details about the experimental set up of the paludiculture system (Figure 1) were given by Giannini et al. (in press).

\section{The multi-adaptive framework and the flowchart-like structure}

The framework was organised as a decision tree with a flowchart-like structure in which each internal node represents a test (T) on the crop behavior, each branch represents the outcomes of the test and each leaf node represents the overall assessment taken after computing all attributes. The path from root to leaf represents the entire assessment process. The tests can determine the exclusion of the tested crop (no suitable) or allow the considered crop to pass the next test by assigning it a degree of suitability (DoS): 1.00 (very high), 0.75 (high), 0.50 (intermediate) and 0.25 (low), in accordance with the specific ranking rules (Table 1).

The threshold values used were derived by literature (when possible) or were based on the Author's experience and convincement. The initial suitability value (ISV) was fixed equal to 100 for all the crops. At each test $\mathrm{T}_{\mathrm{i}}(\mathrm{i}=1,2, \ldots, 7)$, the ISV was multiplied by the correspondent $\mathrm{DoS}_{\mathrm{i}}$ up to obtain the upgraded suitability value $\left(\mathrm{USV}_{\mathrm{i}}\right)$. The $6^{\text {th }}$ and $7^{\text {th }}$ tests were different according to the chain chosen for biomass energy conversion: combustion ( $\mathrm{T}_{\mathrm{a}}$ and $\mathrm{T} 7_{\mathrm{a}}$ ) or anaerobic digestion $\left(\mathrm{T} 6_{\mathrm{b}}\right.$ and $\mathrm{T} 7_{\mathrm{b}}$ ). The final suitability value (FSV) (Eq. 1) was equal to the last value of USV $\left(\mathrm{USV}_{7}\right)$ and can be read, for each crop, in the leaf put at the end of the decision tree (Figure 2 ).

$$
\mathrm{FSV}=\prod_{i=1}^{7} \mathrm{ISV} \times \mathrm{DoS}_{i}
$$

\section{Results and discussion}

According to our experience, the most useful criteria that should guide farmers in the choice of the crops for paludicultural cropping systems were: biological traits, attitude to cultivation, biomass production and biomass quality. These points represent the main stages of the pathway leading to the identification of crops able to satisfy the different constraints put by paludiculture, in accordance with the multi-adaptive approach. Every point can

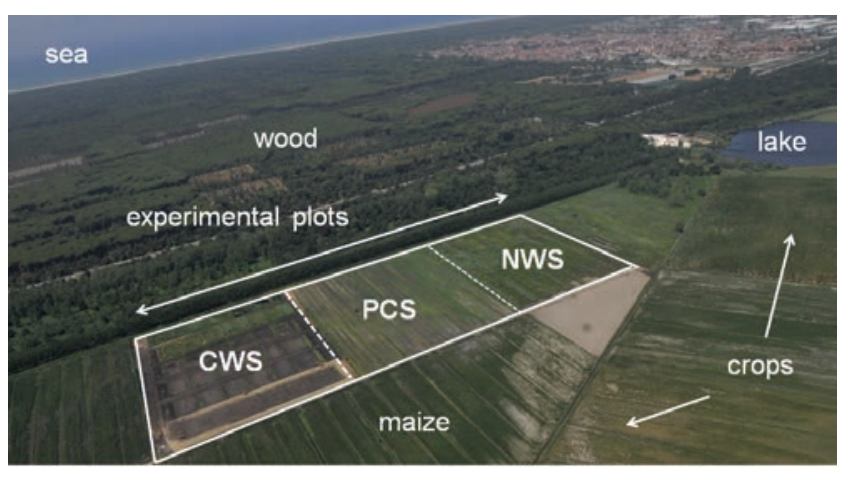

Figure 1. Aerial view of the experimental area where three different treatment systems [constructed wetland system (CWS), paludiculture system (PCS) and natural wetland system (NWS)] are located. The conventionally drained area cultivated with maize is near the pilot field (modified from Giannini et al., in press). 
include one or more features to better define the crop behavior in respect to the considered criterion.

\section{Biological traits}

A first important selection factor in the crop choice was the longevity of the plant species. The use of perennial crops reduces radically the agronomic input requirement compared to those of annual ones (e.g. every year: primary and secondary tillage, seeding, fertilisation, etc.), making their cultivation more suitable in fields not easily accessible because of extreme moisture conditions (Schulte et al., 2006). Moreover the significant reduction of soil tillage frequency leads to a lower rate of soil organic matter mineralisation (Felzer et al., 2004) and then to a better conservation of peat body.

The second feature was the plant capability of re-growing after the cutting that is related to a quick re-sprouting tendency from the stump (coppicing species) or to the activity of underground stems (rhizomatous/stolonifer species). The two strategies are generally matched to the plant structure: woody for coppicing species and herbaceous for rhizomatous/stolonifera species. This determines different pathways affecting important issues in the cropping systems design as the stand duration, the machinery choice for harvesting, the biomass conversion technology, etc.

Another aspect to be carefully considered was the crop harvestability that is the possibility of harvesting expeditiously the crop. Harvest timing (seasonality) and the harvest period duration (plasticity) affect significantly this crop property in relation to the weather conditions and the consequent field accessibility for machinery. In relation to the climate conditions of the cultivation site, the harvest timing can fall on the wet, frozen or dry season limiting or favoring the floating capability of the harvest machines. Moreover, it can be useful to choose plant species that can tolerate both early and delayed harvest in order to prolong the interval duration and to meet the better conditions of accessibility (Karp and Shield, 2008; Dragoni et al., 2015). Plant plasticity is also valuable since farmers can partly drive both the ratio harvestable/total biomass and the quality parameters of the produced biomass by modifying the harvest timing.

In Table 1 the ranking rules for the biological trait tests are reported. The perennial biological cycle and the capability to regrow after the cutting were considered as necessary conditions, thus their absence determines the discard of the crop. About the harvestability we evaluated the number of the weeks suitable for the crop harvesting. To be considered fully suitable a week had to fall both on the season (or fraction of the season) favorable to field accessibility for machinery (seasonality) and on the time interval in which the crop can be harvested without harming its productivity (plasticity).

The results of the framework application on our research were reported in Table 2. None of the considered crops were excluded from the framework, as they were perennial rhizomatous grasses (PRGs) and short-rotation coppice crops (SRCs). Under our experimental conditions (Mediterranean climate), the most favorable harvest season was summer (dry season), whereas spring and

Table 1. Threshold values and correspondent degrees of suitability for all the features foreseen by the framework.

\begin{tabular}{|c|c|c|c|}
\hline Criteria & Features & Tests and threshold values & Dos \\
\hline \multirow[t]{9}{*}{ Biological traits } & \multirow[t]{2}{*}{ Longevity } & Perennial & 1.00 \\
\hline & & Annual & 0.00 \\
\hline & \multirow[t]{3}{*}{ Response to cutting } & Coppice & 1.00 \\
\hline & & Rhizomatous/stolonifer & 1.00 \\
\hline & & Other & 0.00 \\
\hline & \multirow[t]{4}{*}{ Harvestabilty } & $>8$ suitable weeks for crop harvesting* & 1.00 \\
\hline & & From 4 to 8 suitable weeks for crop harvesting* & 0.75 \\
\hline & & From 2 to 3 suitable weeks for crop harvesting* & 0.50 \\
\hline & & $<2$ suitable weeks for crop harvesting* & 0.25 \\
\hline \multirow[t]{4}{*}{ Biomass production } & \multirow[t]{4}{*}{ Relative productivity } & $>+50 \%$ than a control crop $^{\circ}$ & 1.00 \\
\hline & & From 0 to $+50 \%$ than a control crop $^{\circ}$ & 0.75 \\
\hline & & From -50 to $0 \%$ than a control crop ${ }^{\circ}$ & 0.50 \\
\hline & & $<-50 \%$ than a control crop ${ }^{\circ}$ & 0.25 \\
\hline \multirow[t]{4}{*}{ Attitude to cultivation } & \multirow[t]{4}{*}{ Yield gap } & $>+30 \%$ than under ordinary growing conditions ${ }^{\#}$ & 1.00 \\
\hline & & From 0 to $+30 \%$ than under ordinary growing conditions ${ }^{\#}$ & 0.75 \\
\hline & & From -30 to 0\% than under ordinary growing conditions $\#$ & 0.50 \\
\hline & & $<-30 \%$ than under ordinary growing conditions ${ }^{\#}$ & 0.25 \\
\hline \multirow[t]{12}{*}{ Biomass quality } & \multirow[t]{2}{*}{ Heat } & $\mathrm{HHV} \geq 18(\mathrm{MJ} / \mathrm{kg})$ & 1.00 \\
\hline & & $\mathrm{HHV}<18(\mathrm{MJ} / \mathrm{kg})$ & 0.00 \\
\hline & \multirow[t]{4}{*}{ Combustibility } & HEI $>1.00$ (pure number) & 1.00 \\
\hline & & HEI ranges from 0.75 to 1.00 (pure number) & 0.75 \\
\hline & & HEI ranges from 0.50 to 0.75 (pure number) & 0.50 \\
\hline & & $\mathrm{HEI}<0.50$ (pure number) & 0.25 \\
\hline & \multirow[t]{2}{*}{ Methane } & $\mathrm{BMP} \geq 200\left(\mathrm{~mL} \mathrm{CH}_{4} \mathrm{gVS}^{-1}\right)$ & 1.00 \\
\hline & & $\mathrm{BMP}<200\left(\mathrm{~mL} \mathrm{CH}_{4} \mathrm{gVS}^{-1}\right)$ & 0.00 \\
\hline & \multirow[t]{4}{*}{ Digestibility } & $\mathrm{C} / \mathrm{N}$ ratio $<30$ (pure number) & 1.00 \\
\hline & & $\mathrm{C} / \mathrm{N}$ ratio from 30 to 40 (pure number) & 0.75 \\
\hline & & $\mathrm{C} / \mathrm{N}$ ratio from 40 to 60 (pure number) & 0.50 \\
\hline & & $\mathrm{C} / \mathrm{N}$ ratio > 60 (pure number) & 0.25 \\
\hline
\end{tabular}

DoS, degree of suitability; HHV, higher heating value (estimated from carbon, hydrogen and oxygen content); HEI, harmful emission index (estimated from potassium, sodium, sulfur and chlorine content); BMP, biochemical methane potential [according to Triolo et al. (2011)]; C/N carbon and nitrogen content ratio. ${ }^{*}$ To be considered as suitable a week must comply with seasonality and plasticity conditions (see text); ${ }^{\circ}$ contro crop is a crop grown in the same pedoclimate but under drained conditions (see text); ${ }^{*}$ ordinary conditions mean no saturated soil, no high acidity or salinity, rainfed cultivation (see text); ${ }^{\S}$ the two alternative pathways are combustion (heat and combustibility) and biogas conversion (methane and digestibility). 
autumn (generally wet) can hamper harvesting operations because of the increase of soil humidity even if, during the harvesting time, the supply of water to channels is interrupted. A very different range of conditions was observed for crop harvestability (Table 2). Generally the PRGs, with the partial exception of Miscanthus, showed a good adaptability whereas the SRCs did not tolerate to be early harvested (not before all the leaves have fallen).

\section{Biomass production}

The biomass production was an important feature to consider for the crop choice because it allows us to compare the performances of crops regardless of the use to which they are devoted.
Since the carbon content can be estimated as about the half of biomass dry weight, it is also possible to use these data to evaluate the amount of carbon dioxide fixed by the plants and then to quantify the capability of the crops to act as carbon sink (GHGs limiting). From this point of view, the comparison among crops grown under different cultivation conditions (as paludiculture and drainagebased agriculture) becomes possible (Monfreda et al., 2008).

The paludiculture crop production can be evaluated by comparing their aboveground biomass yeld with those of a control crop grown in the same climatic and pedological conditions, but under drained cultivation [relative productivity (RP)]. The ranking rules for biomass production tests are reported in Table 1.

Table 2. The application of framework to our field experimental research: results of the tests (longevity, response to cutting, and harvestability) and the correspondent degree of suitability for all the involved crops.

\begin{tabular}{|c|c|c|c|c|c|c|}
\hline \multirow[t]{2}{*}{ Crops } & \multicolumn{2}{|c|}{ Longevity } & \multicolumn{2}{|c|}{ Response to cutting } & \multicolumn{2}{|c|}{ Harvestability } \\
\hline & Value* & Dos & Value $^{\circ}$ & Dos & Value $\#$ & Dos \\
\hline Arundo & Perennial & 1.00 & Rhizomatous/stolonifer & 1.00 & 10 & 1.00 \\
\hline Miscanthus & Perennial & 1.00 & Rhizomatous/stolonifer & 1.00 & 8 & 0.75 \\
\hline Phragmites & Perennial & 1.00 & Rhizomatous/stolonifer & 1.00 & 12 & 1.00 \\
\hline Salix & Perennial & 1.00 & Coppice & 1.00 & 4 & 0.75 \\
\hline Popolus & Perennial & 1.00 & Coppice & 1.00 & 8 & 0.75 \\
\hline
\end{tabular}

DoS, degree of suitability. *Perennial or annual; ${ }^{\circ}$ rhizomatous/stolonifer or coppice or other; ${ }^{*}$ number of suitable weeks for crop harvesting (see text).
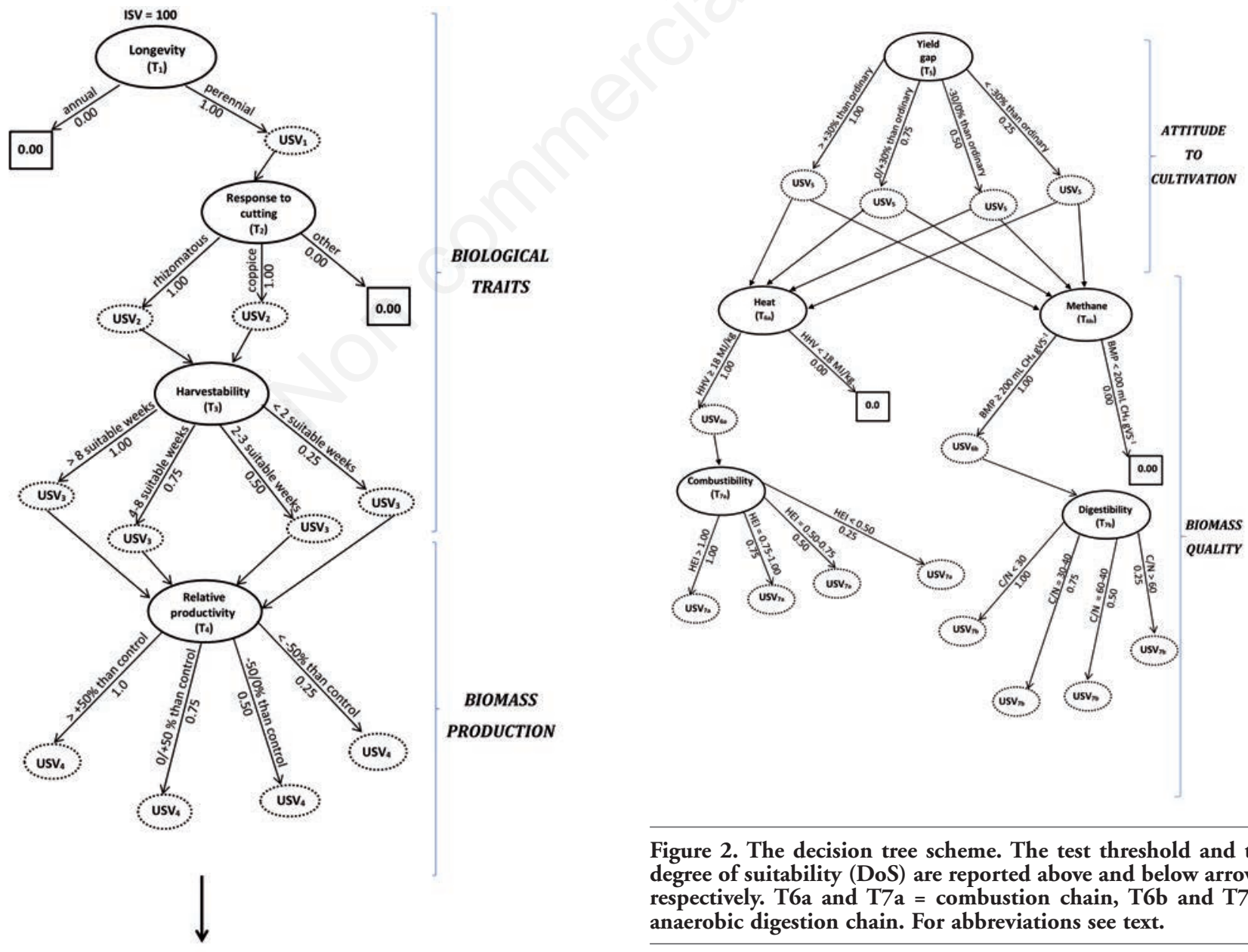

Figure 2. The decision tree scheme. The test threshold and the degree of suitability (DoS) are reported above and below arrows, respectively. $T 6 a$ and $T 7 a=$ combustion chain, $T 6 b$ and $T 7 b=$ anaerobic digestion chain. For abbreviations see text. 
Another point to consider, is the difference between the harvestable biomass and the crop residues that remain on (fallen leaves, crowns) or within (root system) the soil. Both portions are important: the first one defines the marketable production whereas the second one quantifies the potential crop contribution to form new peat (Karp and Shield, 2008; Wichtmann et al., 2010). In this respect, the choice of harvest timing can modify the ratio between the two component of biomass to the aim of enhancing the productivity or the peat forming capability of the crop. Anyhow the crop residues left on/within the field should not be less than a minimum value (generally at least $20 \%$ of the total biomass production) able to ensure the reconstitution of peat consumed in the same time unit (Wichtmann and Joosten, 2007).

The results of the framework application on our research are reported in Table 3. Crop productivity showed a large variability also due to the lag of the SRCs in achieving the full crop production compared to the PRGs. The mean yields over two years (second and third growing season) were: $36.6 \mathrm{Mg} \mathrm{ha}^{-1}$ for Arundo, 24.7 $\mathrm{Mg} \mathrm{ha}^{-1}$ for Miscanthus, $11.5 \mathrm{Mg} \mathrm{ha}^{-1}$ for Phragmites (Giannini et al., in press). For woody crops we chose to consider the last year yield (third growing season) because it was the closest to the full production value. The yield of Populus was equal to $10.3 \mathrm{Mg} \mathrm{ha}^{-1}$ after one year from the cut and the yield of Salix was equal to 12.8 $\mathrm{Mg} \mathrm{ha}^{-1}$ after two years from the cut $\left(6.4 \mathrm{Mg} \mathrm{ha}^{-1} \mathrm{y}^{-1}\right)$ (Giannini et al., in press). The maize yield (as whole plant) was equal to 17.5 $\mathrm{Mg} \mathrm{ha}^{-1}$ (Giannini et al., in press) and was used as control crop for the calculation of relative productivity for all the tested species. The RP values obtained ranged from $+109 \%$ for Arundo to $-63 \%$ for Salix.

\section{Attitude to cultivation}

This aspect is strictly connected to the plant adaptability to the typical characteristics of the wet or rewetted peatlands such as saturated soil conditions (hypoxia or anoxia), acid soil reaction, low hydraulic conductivity, possible soil salinity, etc. The evaluation of the physiological tolerance to grow under these conditions is important to assess the stress level at which the crop was growing and then a possible reduction of the stand duration over time.

To evaluate this attitude, we have to compare the results reported in literature about the same crops grown under ordinary (rainfed, mineral and unsaturated soil, neutral or sub-alkaline $\mathrm{pH}$, etc.) and paludicultural cultivation, all other conditions being equal (i.e. climate and age growth). As much as the difference between the yields gained in the two different cultivation conditions is minimal, the more the species is suitable to paludiculture. The ranking rules for the execution of the test are reported in Table 1.

In absence of comparative data, we can use the stability of the yields over time to evaluate the crop attitude to paludiculture cultivation. Those crops that show a noticeable variation of biomass production, even in a few years, are not advisable. It is possible, indeed, that these differences are the result of the inability of crop to adapt to unfavorable conditions such as a prolonged period of soil submersion. Within a paludiculture cropping system, the cultivation conditions are substantially constant over the years (water and nutrient availability) and a sudden yield decrease can warn us against a next failure of the stand.

Alternatively, the attitude to cultivation can be evaluated by monitoring the state of the crop over time. Beyond the biomass production, other parameters such as the plant survival rate and the plant vigor (e.g. height, color and size of leaves) can be taken into account.

The results of the framework application on our research are reported in Table 3. In our condition the comparison between the yields obtained under paludicultural and ordinary conditions was made possible by the available results of some researches carried out on the surrounding areas (the coastal plain of west-central Italy). All the tested PRGs showed good adaptability to paludiculture cultivation. The Arundo and Miscanthus yields, in fact, were generally similar ( -3 and $-14 \%$ respectively) to those obtained by Angelini et al. (2009) in a long-term field experiment on a mineral soil with a lower water table level (37.7 and $28.7 \mathrm{Mg} \mathrm{ha}^{-1}$ for Arundo and Miscanthus respectively, as average of 12 years). The behavior of Phragmites could be hardly evaluated because of the lack of experimental results in the same area. However, the comparison with other Italian experiments highlights that the yield obtained in our conditions was higher $(+35 \%)$ than those reported by other Italian researches (Molari et al. 2014) on mineral soils irrigated with nutrient enriched waters to simulate the effect of agricultural drainage effluents $\left(8.5 \mathrm{Mg} \mathrm{ha}^{-1}\right)$.

In the case of woody crops (SRCs), the comparison of the yields is complicated both by the influence of the plantation age and the duration of the cutting turn. The Populus yield recorded in $2014\left(10.3 \mathrm{Mg} \mathrm{ha}^{-1}\right)$, one year after cutting and three years after plantation, was lower $(-37 \%)$ than the third year value of a longterm research reported for hybrid poplars (Populus sp.) cut every year $\left(16.4 \mathrm{Mg} \mathrm{ha}^{-1}\right)$ and grown on a mineral soil near our experimental area (Nassi o di Nasso et al., 2010)

Regarding Salix, the data used for the comparison derived from a lysimeter experiment carried out in the previous site on an unfertilised mineral soil. The yields, reported by Guidi et al. (2008), were equal to $6.6 \mathrm{Mg} \mathrm{ha}^{-1}$ adopting a biannual cutting turn, whereas the biomass production obtained in our experimentation at second year of growing was about twice $\left(12.8 \mathrm{Mg} \mathrm{ha}^{-1}\right.$ corresponding to $+94 \%$ ).

Table 3. The application of framework to our field experimental research: results of the tests (relative productivity and yield gap) and the correspondent degree of suitability for all the involved crops.

\begin{tabular}{|c|c|c|c|c|}
\hline \multirow[t]{2}{*}{ Crops } & \multicolumn{2}{|c|}{ Relative productivity } & \multicolumn{2}{|c|}{ Yield gap } \\
\hline & Value* $(\%)$ & Dos & Value $^{\circ}(\%)$ & DoS \\
\hline Arundo & +109 & 1.00 & -3 & 0.50 \\
\hline Miscanthus & +41 & 0.75 & -14 & 0.50 \\
\hline Phragmites & -34 & 0.50 & +35 & 1.00 \\
\hline Salix & -63 & 0.25 & +94 & 1.00 \\
\hline Popolus & -41 & 0.50 & -37 & 0.25 \\
\hline
\end{tabular}

DoS, degree of suitability. ${ }^{*}$ Ratio between the tested crop and a control crop (maize) grown in the same pedoclimate but under drained conditions; ${ }^{\circ}$ ratio between the tested crop and the same crop grown in the same climate but under ordinary soil conditions. 


\section{Biomass quality}

The chemical composition of crops is a key factor in addressing the harvestable biomass towards the most adequate destination. For instance, paludicultural crops could be addressed to different bioenergy supply chains, and making the right decision can increase significantly the profit for farmers.

Regarding the biomass suitability for combustion, the content in some elements can pose technological and environmental threats. $\mathrm{Cl}$ and $\mathrm{S}$ cause the formation of corrosive compounds (acids); $\mathrm{Na}, \mathrm{K}, \mathrm{Ca}, \mathrm{Mg}$ lower the melting point of ashes; $\mathrm{N}$ and $\mathrm{S}$ generate harmful emissions such as $\mathrm{NO}_{\mathrm{x}}, \mathrm{SO}_{\mathrm{x}}$ (Sommersacher et al., 2012).

To evaluate the combustion suitability of biomass we decided to use two indices that can synthetise the information deriving from the elementary composition of the materials that otherwise it would be difficult to interpret. The first was the higher heating value (HHV) of the biomasses that can be directly measured (calorimetric bomb) or calculated by using different correlations. We used the most accurate correlation based on ultimate analysis $(\mathrm{HHV}=-1.3675+0.3137 \mathrm{C}+0.7009 \mathrm{H}+0.0318 \mathrm{O})$ according to Sheng and Azevedo (2005), where $\mathrm{C}, \mathrm{H}$, and $\mathrm{O}$ were respectively carbon, hydrogen and oxygen expressed in percentage. The second index, that we called harmful emission index (HEI), is based on the molar ratio among some component elements: $\mathrm{K}+\mathrm{Na} / 2 \mathrm{~S}+\mathrm{Cl}$ (where $\mathrm{K}$, $\mathrm{Na}, \mathrm{S}$ and $\mathrm{Cl}$ are potassium, sodium, sulfur and chlorine content expressed as moles) and represents the risk of SOx and $\mathrm{HCl}$ emissions during combustion (Sommersacher et al., 2012). The ranking rules for the combustibility tests are reported in Table 1 .

Regarding anaerobic digestion, the composition in terms of lignin, structural (hemicellulose, cellulose) and non-structural carbohydrates (soluble sugars, starch) has to be assessed to estimate the digestibility level of biomass. These compounds are generally acknowledged as the most important in determining the biochemical methane potential (BMP) of biomasses and thus the biomass attitude to biogas production. The conversion into biogas of bio- mass from woody crops shows generally lower rates than herbaceous crops; it is the abundance of recalcitrant fibers and the strength of the bonds among lignin, cellulose and hemicellulose to reduce, in the former ones, the overall degradability level. In the literature, several regression models between BMP and fiber components are reported, allowing predict the BMP from simple chemical traits of the biomass (Triolo et al., 2011; Monlau et al., 2012). For the framework, we chose the relation based on the lignin content: $\mathrm{BMP}=460.1-25.8 \mathrm{~L}$ (where $\mathrm{L}=$ acid detergent lignin content expressed as \% on dry weight), according to Triolo et al. (2011). Indeed, lignification typically reduces the methane yield, but it can also hamper the process when the degradability of a given substrate is too low and its presence can hinder the functioning of the biogas plant.

Also the $\mathrm{C} / \mathrm{N}$ ratio (where $\mathrm{C}$ and $\mathrm{N}=$ carbon and nitrogen contents expressed as $\%$ on dry weight) is an informative, synthetic parameter that gives broad information about biomass digestibility and its optimal value is generally comprised between 20 and 30 (Deublein and Steinhauser, 2011). If the $\mathrm{C} / \mathrm{N}$ of biomass crops does not fall within this range, the biomass can be co-digested with other substrates in order to keep the overall $\mathrm{C} / \mathrm{N}$ balanced. The required degree of co-digestion could be considered as an indicator of ease or unease for the biomass to be digested. For example biomasses having $\mathrm{C} / \mathrm{N}$ between 30 and 40 should be digested in a $1: 1$ ratio with substrates that are in the optimal range; biomasses having $\mathrm{C} / \mathrm{N}$ from 40 to 60 should be digested in a $1: 1$ ratio with $\mathrm{N}$ rich substrates $(\mathrm{C} / \mathrm{N}<20)$; biomasses having $\mathrm{C} / \mathrm{N}>60$ should be codigested in a $1: 1$ ratio with unusually $N$-rich substrates $(\mathrm{C} / \mathrm{N} \approx 5)$ or in lower ratios with optimal substrates $(<1: 3)$.

The ranking rules for the digestibility tests, according to predicted BMP and $\mathrm{C} / \mathrm{N}$, are reported in Table 1 .

Finally, if the biomass is not used for energy purposes (litter, ornament, insulation and raw materials, etc.), the evaluation of the biomass quality is based especially on the physical characteristics of the material (density, robustness, flexibility, soundproofing,

Table 4. The application of framework to our field experimental research: combustion chain. Results of the tests (higher heating value and harmful emissions index) and the correspondent degree of suitability for all the involved crops.

\begin{tabular}{lcccc} 
Crops & Values $(\mathrm{MJ} / \mathrm{kg})^{*}$ & HHV & Halues (pure number) & Dos \\
Arundo & $19.1( \pm 0.41)$ & 1.00 & $0.63( \pm 0.11)$ & 0.50 \\
Miscanthus & $18.8( \pm 0.16)$ & 1.00 & $0.39( \pm 0.03)$ & 0.25 \\
\hline Phragmites & $18.6( \pm 0.75)$ & 1.00 & $0.65( \pm 0.04)$ & 0.50 \\
Salix & $19.6( \pm 0.02)$ & 1.00 & $1.00( \pm 0.06)$ & 1.00 \\
\hline Popolus & $19.7( \pm 0.07)$ & 1.00 & $1.06( \pm 0.52)$ & 1.00 \\
\hline
\end{tabular}

HHV, higher heating value; HEI, harmful emissions index; DoS, degree of suitability. *Estimated according to Sheng and Azevedo (2005); ${ }^{\circ}$ estimated according to Sommersacher et al. (2012). Standard deviation values are reported in brackets.

Table 5. The application of framework to our field experimental research: biogas conversion chain. Results of the tests (biochemical methane potential and carbon-nitrogen ratio) and the correspondent degree of suitability for all the involved crops.

\begin{tabular}{lcccc} 
Crops & Values* & BMP & Values & C/N \\
& $362( \pm 3.0)$ & 1.00 & $30.7( \pm 4.0)$ & 0.75 \\
Arundo & $305( \pm 9.8)$ & 1.00 & $42.6( \pm 7.7)$ & 0.50 \\
Miscanthus & $247( \pm 1.8)$ & 1.00 & $19.6( \pm 1.6)$ & 1.00 \\
\hline Phragmites & & Dos & \\
\hline
\end{tabular}

BMP, biochemical methane potential; $\mathrm{C} / \mathrm{N}$, carbon-nitrogen ratio; DoS, degree of suitability. ${ }^{*}$ Estimated according to Triolo et al. (2011); ${ }^{\circ}$ calculated on the basis of analytical results. Standard deviation values are reported in brackets. 
Table 6. The application of the framework to the tested crops in our field experimental research.

\begin{tabular}{|c|c|c|c|c|c|c|c|c|c|c|c|}
\hline Crops & ISV & $\begin{array}{c}\mathrm{T}_{1} \\
\mathrm{USV}_{1}\end{array}$ & $\begin{array}{c}\mathrm{T}_{2} \\
\mathrm{USV}_{2}\end{array}$ & $\begin{array}{c}\mathrm{T}_{3} \\
\mathrm{USV}_{3}\end{array}$ & $\begin{array}{c}\mathrm{T}_{4} \\
\mathrm{USV}_{4}\end{array}$ & $\begin{array}{c}\text { Tests } \\
\mathrm{T}_{5} \\
\text { USV }_{5}\end{array}$ & $\begin{array}{c}\mathrm{T}_{6 \mathrm{a}} \\
\mathrm{USV}_{6 \mathrm{a}}\end{array}$ & $\begin{array}{c}\mathrm{T}_{7 \mathrm{a}} \\
\mathrm{USV}_{7 \mathrm{a}}\end{array}$ & $\begin{array}{c}\mathrm{T}_{6 \mathrm{~b}} \\
\mathrm{USV}_{6 \mathrm{~b}}\end{array}$ & $\begin{array}{c}\mathrm{T}_{7 \mathrm{~b}} \\
\mathrm{USV}_{7 \mathrm{~b}}\end{array}$ & FSV \\
\hline Arundo & 100 & 100 & 100 & 100 & 100 & 50 & 50 & 25 & - & - & 25 \\
\hline Miscanthus & 100 & 100 & 100 & 75 & 56 & 28 & 28 & 7 & - & - & 7 \\
\hline Phragmites & 100 & 100 & 100 & 100 & 50 & 50 & 50 & 25 & - & - & 25 \\
\hline Arundo & 100 & 100 & 100 & 100 & 100 & 50 & - & - & 50 & 38 & 38 \\
\hline Miscanthus & 100 & 100 & 100 & 75 & 56 & 28 & - & - & 28 & 14 & 14 \\
\hline Phragmites & 100 & 100 & 100 & 100 & 50 & 50 & - & - & 50 & 50 & 50 \\
\hline Salix & 100 & 100 & 100 & 75 & 19 & 19 & 19 & 19 & & & 19 \\
\hline Popolus & 100 & 100 & 100 & 75 & 38 & 9 & 9 & 9 & - & - & 9 \\
\hline
\end{tabular}

ISV, Initial suitability value; $\mathrm{T}_{1}$, longevity; $\mathrm{T}_{2}$, response to cutting; $\mathrm{T}_{3}$, harvestability; $\mathrm{T}_{4}$, relative productivity; $\mathrm{T}_{5}$, yield gap, combustion chain; $\mathrm{T}_{6 \mathrm{a}}$, higher heating value; $\mathrm{T}_{7 \mathrm{a}}$, harmful emission index; $\mathrm{T}_{6 \mathrm{~b}}$, biochemical methane potential; $\mathrm{T}_{\mathrm{pb}}$, carbon and nitrogen content ratio; $\mathrm{USV}_{1-7 \mathrm{~b}}$, upgrade suitability values; FSV, final suitability value. For perennial rhizomatous grasses, both bioenergy chains were evaluated.

waterproofing, etc.) (Kobbing et al., 2013) and it requires the use of specific methodologies which lie outside the aim of this paper.

The evaluation of suitability for energy conversion of the biomass crops tested in our experimental research were reported in Tables 4 and 5. In the case of combustibility (Giannini et al., 2016), although the concentrations of the most important elements $(\mathrm{Cl}, \mathrm{N}, \mathrm{S})$ were higher than the threshold values suggested (Obernberger et al., 2006), the HHVs were promising (18-19 MJ $\mathrm{kg}^{-1}$ ) for all the crops. The HEI values were more diversified: Salix and Populus showed a good attitude to combustion (HEI was equal to 1.06 and 1.00 respectively) whereas the PRGs were definitely less suitable for combustion. In particular, Miscanthus ranked the last class $(\mathrm{HEI}=0.39)$.

Regarding digestibility, the acid detergent lignin content (ADL) of rhizomatous crops harvested in late summer was found to range between 3 and 4\% in Arundo, 5 and 6\% in Miscanthus, 8 and $9 \%$ in Phragmites and the predicted BMP varied accordingly, from 362 to $248 \mathrm{~mL} \mathrm{CH}_{4}$ per gram of organic matter and therefore higher than threshold value of biogas conversion, fixed equal to 200 (Table 1).

At the same harvest time, the $\mathrm{C} / \mathrm{N}$ ratios were found to be generally lower in Phragmites than in Arundo and Miscanthus (equal to 20,31 and 43 , respectively) showing a descending order of the biomasses in digestion suitability.

\section{Overall evaluations}

In Table 6 a synoptic outline of the framework application to our case study was proposed. In our conditions, the PRGs were generally more suitable than SRCs, if directed to the biogas conversion chain, and among the formers Phragmites and Arundo showed the highest FVS (50 and 38 respectively). Salix was better than Populus that seemed not to be a crop suitable the paludiculture exploitation (FVS=9). Salix had a FVS higher even than Miscanthus (19 vs 14) and its main deficiency was the low relative productivity.

This ranking may be modified in the future as a result of a change in the crop behavior. For example Arundo seemed to show a decrease in yield, at the last harvest (year 2015, data not shown), likely due to its partial adaptability to waterlogging conditions (Quinn et al., 2015), whereas the yield of Salix is expected to improve due to the full production achievement.

\section{Conclusions}

The crop choice for paludiculture has to meet different agronomic criteria to ensure the success of the stand. Then, it is important that each plant species is evaluated taking into account all the possible characteristics that can interact with the management and the performances of paludiculture cropping systems (multi-adaptive approach). The step-by-step pathway defined by the decision tree structure established a checklist able to verify the actual level of suitability that can be ascribed to every crop. On the basis of the required information (biology, productivity, adaptability and quality), we can discriminate the compliance of different crops to paludiculture conditions and the proposed framework can constitute a useful tool to support the farmer's decision. The experimental dataset used in this paper was too limited to provide generalisable results and only an application on a larger scale would allow a better calibration of the threshold values and of the DoSs, indispensable for a proper functioning of framework. Conversely, the introduction of trade-off values among all the adopted criteria to weigh differently the contribution of every feature on the FSV calculation can be determined only by considering the site-specific conditions that play a crucial role in the design of sustainable cropping systems.

Finally, the discussed issues could contribute to define the main guidelines for future genetic programmes about paludiculture crop improvement.

\section{References}

Abel S, Couwenberg J, Dahms T, Joosten H, 2013. The database of potential paludicultre plants (DPPP) and results for Western Pomerania. Plant Div. Evol. 103:219-28.

Angelini LG, Ceccarini L, Nassi o Di Nasso N, Bonari E, 2009. Comparison ofArundo donax L. and Miscanthus x giganteus in a long-term field experiment inCentral Italy: analysis of productive characteristics and energy balance. Biomass Bioen. 33:635-43.

Cicek N, Lambert S, Venema HD, Snelgrove KR, Bibeau EL, Grosshans R, 2006. Nutrient removal and bio-energy production from Netley-Libau Marsh at Lake Winnipeg through annual biomass harvesting. Biomass Bioen. 30:529-36.

Deublein D, Steinhauser A, 2011. Biogas from waste and renew- 
able resources: an introduction. John Wiley \& Sons, Hoboken, NJ, USA.

Dragoni F, Nassi o Di Nasso N, Tozzini C, Bonari E, Ragaglini G, 2015. Aboveground yield and biomass quality of giant reed (Arundo donax L.) as affected by harvest time and frequency. BioEnergy Res. 8:1-11.

Felzer B, Kicklighter D, Melillo J, Wang C, Zhuang Q, Prinn R, 2004. Effects of ozone on net primary production and carbon sequestration in the conterminous United States using a biogeochemistry model. Tellus B. 56:230-48.

Giannini V, Oehmke C, Silvestri N, Wichtmann W, Dragoni F, Bonari E, 2016. Combustibility of biomass from perennial crops cultivated on a rewetted Mediterranean peatland. Ecol Engin 97:157-69.

Giannini V, Pistocchi C, Silvestri N, Volterrani M, Cantini V, Bonari E, 2015. Preliminary investigation on the potential use of two C4 turfgrass species to reduce nutrient release in a Mediterranean drained peatland. Environ. Sci. Pollut. Res. 22:2396-405.

Giannini V, Silvestri N, Dragoni F, Pistocchi C, Sabbatini T, Bonari $\mathrm{E}$, in press. Growth and nutrient uptake of perennial crops in a paludicultural approach in a drained Mediterranean peatland. Ecol. Eng.

Guidi W, Piccioni E, Bonari E, 2008. Evapotranspiration and crop coefficient of poplar and willow short-rotation coppice used as vegetation filter. Bioresour. Technol. 99:4832-40.

Holden J, Evans MG, Burt TP, Horton M, 2006. Impact of land drainage on peatland hydrology. J Environ. Qual. 35:1764-78.

Karp A, Shield I, 2008. Bioenergy from plants and the sustainable yield challenge. New Phytol. 179:15-32.

Köbbing JF, Thevs N, Zerbe S, 2013. The utilisation of reed (Phragmites australis): a review. Mires Peat 13:1-14.

Litaor MI, Eshel G, Sade R, Rimmer A, Shenker M, 2008. Hydrogeological characterization of an altered wetland. J. Hydrol. 349:333-49.

Molari G, Milani M, Toscano A, Borin M, Taglioli G, Villani G, Zema DA, 2014. Energy characterisation of herbaceous biomasses irrigated with marginalwaters. Biomass Bioen. 70:3929.

Monfreda C, Ramankutty N, Foley JA, 2008. Farming the planet: 2. Geographic distribution of crop areas, yields, physiological types, and net primary production in the year 2000. Global Biogeochem. Cy. 22:GB1022.

Monlau F, Sambusiti C, Barakat A, Guo XM, Latrille E, Trably E, Steyer JP, Carrere H, 2012. Predictive models of biohydrogen and biomethane production based on the compositional and structural features of lignocellulosic materials. Environ. Sci. Technol. 46:12217-25.

Nassi o di Nasso N, Guidi W, Ragaglini G, Tozzini C, Bonari E, 2010. Biomassproduction and energy balance of a 12-year-old short-rotation coppice poplarstand under different cutting cycles. GCB Bioenergy 2:89-97.
Obernberger I, Brunner Th, Bärnthaler G, 2006. Chemical properties of solid biofuels significance and impact. Biomass Bioen. 30:973-82.

Pellegrino E, Bosco S, Ciccolini V, Pistocchi C, Sabbatini T, Silvestri N, Bonari E, 2014. Agricultural abandonment in Mediterranean reclaimed peaty soils: long-term effects on soil chemical properties, arbuscular mycorrhizas and CO2 flux. Agr. Ecosyst. Environ. 199:164-75.

Quinn LD, Straker KC, Guo J, Kim S, Thapa S, Kling G, Voigt TB, 2015. Stress-tolerant feedstocks for sustainable bioenergy production on marginal land. BioEnergy Res. 8:1-20.

Schulte LA, Asbjornsen H, Liebman M, Crow TR, 2006. Agroecosystem restoration through strategic integration of perennials. J. Soil Water Conserv. 61:164-9.

Sheng C, Azevedo JLT, 2005. Estimating the higher heating value of biomass fuels from basic analysis data. Biomass Bioen. 28:499-507.

Silvestri N, Pistocchi C, Sabbatini T, Rossetto R, Bonari E, 2012. Diachronic analysis of farmers' strategies within a protected area of central Italy. Ital. J. Agron. 7:139-45.

Sommersacher P, Brunner T, Obernberger I, 2012. Fuel indexes: a novel method for the evaluation of relevant combustion properties of new biomass fuels. Energ. Fuel. 26:380-90.

Triolo JM, Sommer SG, Møller HB, Weisbjerg MR, Jiang XY, 2011. A new algorithm to characterize biodegradability of biomass during anaerobic digestion: influence of lignin concentration on methane production potential. Biores. Technol. 102:9395-402.

Verhoeven JTA, 2014. Wetlands in Europe: perspectives for restoration of a lost paradise. Ecol. Eng. 66:6-9.

Verhoeven JTA, Koerselman W, Meuleman AFM, 1996. Nitrogenor phosphorus-limited growth in herbaceous, wet vegetation: relations with atmospheric inputs and management regimes. Trends Ecol. Evol. 11:494-7.

Wichtmann W, Couwenberg J, 2013. Reed as a renewable resource and other aspects of paludiculture. Mires. Peat. 13:1-2.

Wichtmann W, Joosten H, 2007. Paludiculture: peat formation and renewable resources from rewetted peatlands. IMCG Newslet. 3:24-8.

Wichtmann W, Schäfer A, 2007. Alternative management options for degraded fens. Utilisation of biomass from rewetted peatlands. In: Okruszko et al. (eds.). Wetlands: monitoring, modeling and management. Taylor \& Francis Group, London, UK, pp. 273-9.

Wichtmann W, Tannerberger F, Wichmann S, Joosten H, 2010. Paludiculture is paludifuture. Peatlands Int. 1:48-51.

Wichtmann W, Wichmann S, 2011. Environmental, social and economic aspects of a sustainable biomass production. J. Sustain. Energy Environ. 77:81.

Zedler JB, 2003. Wetlands at your service: reducing impacts of agriculture at the watershed scale. Front. Ecol. Environ. 1:6572 . 